\title{
チャウシェスク政権前期における正教会と歴史遺産政策 ルーマニアにおけるポスト社会主義の文化遺産政策と世界遺産の役割に関する研究- 1 ORTHODOX CHURCH AND HERITAGE POLICY IN EARLY CEAUŞESCU PERIOD
}

A study on heritage management and role of World Heritage in post-socialist Romania - 1

\author{
舘㟝 麻衣子*1, 花 里 利一*2, 三 宅 理 一 *3 \\ Maiko TATEZAKI, Toshikazu HANAZATO and Riichi MIYAKE
}

\begin{abstract}
Analysing the transformation from socialist to post-socialist heritage policy in Romania from 1960's to 1990's, this paper focuses on the policy-making and implementation processes in the early Ceauşescu period in term of Orthodox religious heritage from the following points.

1. Formation of socialist heritage policy till 1970's in relation with the ideological cultural campaign over the Romanian Orthodox Church.

2. Priority of certain medieval Orthodox monasteries as representative Romanian heritages and their restoration led by Ioana Grigorescu

3. Implementation of systematization policy for promoting urbanization, which caused serious crisis of the historical cities in Romania
\end{abstract}

Keywords: Socialist Authority, Heritage Policy, Romania, Systematization, Orthodox Church, Ioana Grigorescu 社会主義政権, 遺産政策, ルーマニア, 国土体系化, 正教会, イオアナ・グリゴレスク

\section{1. 目的. 方法}

\section{1. 背景}

1989 年に連鎖的に引き起こされた東欧の社会主義国家の崩壊は、 政治経済面だけでなく文化の枠組みにも決定的な変化を及ぼした。 その最後に位置づけられる同年 12 月のルーマニア革命は、自主独 立の社会主義路線にともなって強化されたプロパガンダ的文化政策 の破綻をもたらすが、建築遺産の領域においても根本的な変化を余 儀なくされた。それまでのイデオロギー重視の「社会主義的」な遺 産行政が抜本的に改編され、ユネスコ世界遺産等を軸として国際社 会との連携をはかる新たな政策が導入される。こうした脱社会主義 化のプロセスはこの国の地域文化の基層を形成するルーマニア正教 会の復権を促し、教会が本格的に遺産保護に乗り出寸契機ともなっ た。本研究は、第二次大戦後に始まった社会主義時代とりわけ 1965 年以降のチャウシェスク政権期と 1990 年以降の脱社会主義期を比 較検討し、正教会の関与の仕方と遺産保護体制の転換について考察 を重ねるとともに、ユネスコ世界遺産政策が及ぼしたインパクトに ついて精査し、「チャウシェスク政権前期における遺産政策」、「ャ ウシェスク政権後期における宗教施設の破壊」、「ルーマニア革命と 世界遺産政策の導入」、「修道院保存修復事業の実施事例」の 4 編に 分けて論を展開するものである。

\section{2. 本論文の目的}

1977 年のヴランチャ地震を境として、ルーマニアの遺産政策が大 きく転換するが、本論文ではそれ以前の「チャウシェスク政権前期」 を対象とする。社会主義政権によって確立されたイデオロギー先行
的な文化政策と歴史遺産保護の関係に着目し、国民の間で共有され てきた正教会の資産がこの時期にどのようなかたちで解体／継承／ 変質のプロセスを辿ったかを明らかにする。比較的リベラルな専門 家集団（建築家、考古学者、美術史家、修復家）を擁する文化遺産 当局の政権内での位置づけ、修道院や教会等の正教会の歴史的資産 に対する政権の介入を当時の文書、残された図面などより、ヴラン チャ地震以前の歴史遺産政策の特質を洗い出す。

\section{3. 先行研究}

2000 年代以降、EU の枠組みの中で東欧の社会主義時代の評価を めぐる議論が活発化し、仏、英、蘭等で共同研究・国際会議が繰り 返し実施される。チャウシェスク期の都市政策については、イラリ オン・ツィウ（注 32）、リリアナ・イュガらの研究成果（参考文献 6）が公開される。論点としては、その時代を象徵する国土体系化 （sistematizarea）政策について、事例研究を踏まえた実態把握、 行政手続き、農村部の疲弊化などが中心となるが、歴史都市遺産に 着目した研究はブカレストを除いて見当たらない。

チャウシェスク期の歴史遺産問題については、アーカイブ化が進 んでおらず、研究も未着手である。

他方、日本においては、1990 年代に行われたユネスコ日本信託基 金による同国の世界遺産保存修復事業を契機として学術交流が進み、 修復建築家イオアナ・グリゴレスクの展覧会が研究者らの主導で日 本建築学会にて実施された注1)。その折に編纂されたモルドヴァの中 世遺産に関する研究（参考文献 5）に研究者を含む日本・ルーマニ アの研究成果が収録されたが、1960 年代のルーマニアの歴史遺産政

\footnotetext{
*1 陎文化財保存計画協会 主任研究員・修士 (工学 (三重大学大学院工学研究科 大学院生)

*2 三重大学大学院工学研究科 教授. 工博

*3 東京理科大学理工学部 客員教授.工博
}

Senior Researcher, Japan Cultural Heritage Consultancy, MEng. (Grad. Student, Graduate School of Engineering, Mie University) Prof., Graduate School of Engineering, Mie University, Dr.Eng.

Visiting Prof., Tokyo University of Science, Dr.Eng. 
策に関する研究は含まれていない。

\section{4. 方法}

本論文の方法は、先行研究の整理を下敷きとして、以下の 2 点に 集約される。

（1）当時の公文書は閲覧することができないが、歴史記念物局より 刊行された『歴史的記念物紀要』（Buletinul Monumentelor Istorice）をもとに当時の歴史遺産事業に関する詳細な情報を収 集し、ヴランチャ地震以前の遺産政策を分析する。

（2）関係者へのヒヤリング調査。ルーマニアの歴史遺産政策に携わ った専門家、官庁関係者、教会関係者等にヒヤリング。特に、 遺産政策上の重点地域であったスチャヴァ県における事業につ いては、同地で多くの事業を手掛けたイオアナ・グリゴレスク 本人より生前に提供された図面資料を分析する。

\section{2. 社会主義政権における文化遺産政策}

\section{1. 社会主義体制下における文化政策}

第二次大戦後のルーマニアは、1947 年に王政を廃止してルーマニ ア人民共和国を建国し、ソビエト連邦の強い影響下に社会主義体制 を確立していく。ルーマニアの共産党政権の特徴は、ゲオルギュ $=$ デジによる権力の掌握期から常にソ連との距離の取り方が意識され、 特にスターリン死去後になって民族独立路線が顕著となった点であ ろう。1965 年以降のチャウシェスク政権はその傾向がさらに強まる。 社会主義国家における文化行政は、党のプロパガンダを目的とし てイデオロギー支配を強める方向に動くのが一般的であるが、伝統 的に土着性が高く民族感情の強いルーマニアにおいては他の東欧諸 国とは異なった力が働いている。本来、政権が発動した企業国有化、 農村の集団化、重工業化といった強権的で中央集権的な施策を徹底 させるべく、国民意識を「社会主義文化」に向かって鼓舞扇動する ものでなければならないが、国民の間で根強いキリスト教的な社会 規範や信仰心、あるいは伝統的な反露 (ソ) 感情との対決を回避し、 逆にそれらを巧みに取り込んだ政策運営に腐心したことに着目した い。とりわけ人々の日常生活に深く浸透し圧倒的な影響力をもつル 一マニア正教会に対しては飴と鞭を使い分けて適度の妥協をはかり つつ、その資産を利用することでルーマニア固有の歴史性を担保す ることになる注 2)。正教会に対して徹底的な弾圧で臨んだソ連の宗教 政策とはその点で大きく異なっていた。

社会主義政権の特徵は、共産党一党独裁ゆえの党の国家機関に対 する優位性が明確に表れている点にある。すなわち、党の常務委員 会が、国会に相当する国民大議会（Marea Adunare Nationala）に よって任命された閣僚会議（Consiliul de Ministri）の上に立つ。 文化政策の担当省庁としては、当初は王政時代の組織を引きずって 文化省（Ministerul Culturii）が置かれていたが、何度かの改組を 経た後注 3)、チャウシェスク政権下で、党と閣僚会議の双方に従属す る社会主義文化教育常務委員会 (Consiliul Culturii și Educației Socialiste) 注 4) が統括することになった注5)。

ルーマニアの文化政策が統合化かつ強権化されるのは、1971 年、 党書記長のチャウシェスクが中国と北朝鮮を訪問し、文化大革命や 個人崇拝に強い刺激を受けたことが直接のきっかけといわれる。こ の年に設置された社会主義文化教育常務委員会は、従来の文化領域 に歴史遺産（文化財保護）を取り込み、さらに教育部門と合体させ
ることで、絶大な権限が与えられた。社会主義的な「新しい人間」

注 6) の育成と環境づくりを究極の目標として、従来のプロパガンダを 越える総合的な文化行政を専権的に行うことが可能となった。奇妙 なまでに理想化された「ホモ・ソヴィエティクス」注 7) が社会を支配 するという、教条主義と誇大妄想の入り混じった言説がこの国の文 化の仕組みを動かすようになったのである。

\section{2. 歴史遺産政策の変化}

ルーマニアの歴史遺産をめぐる政策は 19 世紀の後半以降、フラ ンス型のモデルを追求し、教会建築や宮殿などの領域でそれなりの 研究と修復実績を残している。なかでも第一次大戦後の戦間期にお いては、ロシアに組み入れられていたベッサラビア等の領土が回復 したこともあって、過去のルーマニアの栄光を讃える大ルーマニア 主義が台頭し、積極的な歴史遺産修復事業が展開された。その任を 負ったのが 1860 年に設置された歴史的記念物委員会（Comisia Monumentalor Istorice) であり、ヴィオレ=ル＝デュク式の中世 建築研究を範として着実な成果を重礼ていた。シュテファン・バル シュ 注 8) に代表されるすぐれた修復建築家を擁し、設計・施工におい て遜色のない仕事を見せている。

人民共和国成立にともない、歴史的記念物委員会は 1948 年にな って廃止の憂き目にあう。文化財保護の任は暫定的にアカデミーの 中に設けられた文化課（Departamentlul Cultelor）が受け持つが、 その主たる任務は博物館の維持にすぎなかった。従来行われていた 教会建築や宮殿の保護が王党派の残㳯としての扱いを受け、加えて 集合住宅の建設が喫緊の課題となったことで、建築遺産の保護は実 質的に無視される注 ${ }^{9)}$ 。しかし、スターリン批判が巻き起こるととも に、歴史遺産に対しても柔軟な姿勢が見え始め、1955 年には、博物 館の機能を強化し歴史遺産の保護活用を進めるべく、文化財保護修 復活用法（Regulmmentul privind protejarea, restaurarea şi folosirea monumentelor de cultură) が制定される。党中央におい ても、社会主義化という前提をつけつつ、歴史文化の取り込みが論 議されるようになり、1957 年の党政治局において採択された「労働 者階級のための愛国教育の改善に向けた計画」が将来の方向を決定 づけた注 10)。その結果が、1959 年の歴史的記念物局 (Directie a Monumentelor Istorice =DMI)の設置である。文化政策とは切り離 し、建設省にあたる建設・建築・国土体系化国家委員会 (Comitetului de Stat pentru Construcții, Arhitectura și Sistematizare=CSCAS) の中に組み入れることで、国土計画の一環として歴史遺産の保護が 位置付けられ、10 年余りを経て、かつての歴史的記念物委員会の機 能が復活したわけである。

\section{3. チャウシェスク政権における文化遺産政策の転換}

1965 年に急死したゲオルギュニデジの後を継いだチャウシェス クは、当初、榣健な社会主義路線を継承し、民族性にこだわった政 治文化を前面に押し出した。その旗振り役となったのが、同年に文 化芸術国家委員会委員長（文化大臣に相当）に就いた建築家ポンポ リウ・マコヴェイ注 11)で、映画演劇や造形美術の領域で積極的な振 興策を打ち出すことになる。西欧のヌーヴェル・ヴァーグに対応す ベく、ルーマニアのアイデンティティを基軸とした斬新な映像表現 は国際的にも注目される注 ${ }^{12)}$ 。しかし、民族独立路線の強化がイン フラ計画や建設プログラムに及ぶに到って、イデオロギーを極端に 打ち出した過激な国土計画（国土体系化）が上位計画となり、大衆 
扇動的な「文化の家」プログラムや「社会主義的」な遺産活用計画 が優先される。旧弊に囚われず社会主義を標榜してやまない「新し い人間」を想定した歴史街区の再編が次々と実施に移され、従来の 意味における遺産保護とは異なった怨意的な歴史の解釈と流用が目 立つようになった。

1971 年に発足した社会主義文化教育常務委員会は、文化政策と歴 史遺産政策を合体させ、加えて教育をも統括する。本来は経験主義 的な下地の上に成り立っていた歴史遺産保護がイデオロギー重視の 歴史遺産の活用にシフトしたといってもよい。その考え方を全面的 に打ち出したのが 1974 年の第 11 回党大会で、それを機にルーマニ アの「国土体系化」は立法化され、自治体に後に述べるような都市・ 農村の体系化計画の策定を義務付ける。文化遺産保護を担う部局も そのサイクルに編入され、社会主義文化教育常務委員会の下に文化 遺産局（Direcția Patrimoniului Cultural Național）として組み入 れられた。

\section{4. 正教会の役割}

ルーマニア正教会は、何度も解体の危機に見舞われながらも最終 的には社会主義政権と共存しえた点で、ソ連におけるロシア正教会 とは大きく異なった道を歩んだ。共産党は宗教を敵対視しつつも、 その社会生活への影響力を政治的に利用することを考一、懷柔と弾 圧の双方を繰り返す。人民共和国の発足にともない 1948 年には宗 教法を改正し、その後の 10 年は王党派に近いとされた正教会を徹 底的に締め付け、教会組織の根本からの再編を目論む。教会への監 視を強化し、教会会議（シノド）や人事に直接的に介入し、民主ブ ロックに与する司祭を宗教大臣に取り立てることもあれば注 ${ }^{13)} 、$ 正 教会最高位の総主教に任命することもあった注 ${ }^{14)}$ 。また、密かに司 祭や修道士を秘密警察のエージェントとなしたケースも多々報告さ れている注 ${ }^{15)}$ 。反抗的な司祭や修道士・修道女の投獄、教会財産の 没収、神学校の閉鎖が相次ぎ、特に 1950 年代の終わりには教会や 修道院の閉鎖や取り壊しが 100 件近くに及んだ注 ${ }^{16)}$ 。チャウシェス クが政権トップに就く頃には、正教会の力は徹底的に削ぎ落とされ、 党に対して従順で協力的な人心掌握機関へと姿を変えていた注 ${ }^{17)}$ 。 その代償として国の財政支援を受ける「国家教会」の地位は保証さ れ、聖職者の給与も戦前と同様、国（宗教課）が賄っていた。

1965 年に始まるチャウシェスク政権は、こうした正教会に対して むしろ宥和的な態度を取るようになる。ルーマニア史における正教 会の役割を「正教会は人民の信仰心の統一を保ち、人民の生活の基 本を守り、国民的統合の達成に寄与した」注 18$)$ として評価し、国家 のアイデンティティづくりにおける正教会の参与を積極的に促した。 その見解を視覚化するのが、歴史性の高い建築遺産であり、特に中 世から近世にかけての修道院や教会は城塞や宮殿と並んで意図的に 記念物化された。芸術性が高く建築物として傑出した価值をもつと されたヴオロネッツ、スチェヴィツア、プトナ、クルタ・デ・アル ジェシュ等の修道院がその代表格である注 ${ }^{19)}$ 。ただ、その位置づけ は、フレスコ画で名高いヴォロネッツに示されるように、修道院復 興ではなく、観光拠点としての整備をともなった脱宗教的な扱いと なっていた点に注意したい。

\section{5. 修道院の修復}

1959 年に歴史的記念物局（DMI）が発足し、それまで宗教課の 下で細々と続いていた宗教建築の維持修理を本格的な保存修復とし
て施策の練り直しを図り、緊急調査を踏まえた事業化に乗り出す。 今回の文献調查において、歴史的記念物局が刊行した『紀要』が 入手できた。公文書が未整理の現段階においては、事業費の配分を 示寸唯一の史料である。これを表にとりまとめ (Table 1)、さらに 地図上に当時の県別に事業費をプロットしたものが fig.1である。

1960 年代の遺産保護事業総数が継続中のものを含め 95 件を数え、 そのうちルーマニア正教会の案件は 59 件に及ぶ注 20$)$ 。全事業のうち 実に $2 / 3$ が正教会の建造物で占められている。事業費規模で見ると、 10 年間の総事業費 $155,789,554$ レイのうち $41.7 \%$ が正教会の資産 に振り向けられた注 ${ }^{21)}$ 。カトリック、プロテスタントにイスラーム のモスクを加えた宗教建築全体では半数の $55.3 \%$ となる。

この一覧表から読み取れるのは、当時のルーマニアの全 39 県お よびブカレスト特別市の中で、北西部モルドヴァ地方のスチャヴァ 県とトランシルヴァニア地方のブラショフ県、ワラキア地方のコン スタンツァが突出して予算規模が大きい点である (Fig.1、Table 1)。 それぞれ、15 件の案件に 24,515,484レイ（総事業費の $15.7 \%$ )、5 件に対し 19,803,068 レイ $(12.7 \%) 、 5$ 件に対し 16,141,012 レイ (10.4\%) が投入されている注 22$)$ 。中世モルドヴァ公国の都スチャ ヴァを擁するスチャヴァ県は中世の正教修道院を多数抱え、住民の 信仰心も篤いとされる。修復案件も大半が正教会の施設である。一 方、ハンガリー系住民とドイツ系住民が多いトランシルヴァニアの ブラショフ県では福音派の教会建築よりも城塞の大規模修復に主眼 が置かれている。また、ワラキア地方のコンスタンツア県は、古代 ローマに関する遺跡が対象である。

個別の事業費を比較すると、宗教建築でもっとも大きいのは、ワ ラキア地方の重点案件であったヴルチャ県のホレズ修道院で、次い で、スチャヴァ県のスチェヴィツァ修道院、ドラゴミルナ修道院と なっている。後に、ホレズ修道院とスチェヴィツァ修道院は、その 後世界遺産リストに記載されることとなる注 23$) 。$

\section{6. イオアナ・グリゴレスクの役割}

社会主義政権下、正教会の修道院や教会の修復がもつとも進むの は 1960 年代後半から 70 年代初頭であるが、さらに注目す心゙きは、 スチェヴィツア、ドラゴミルナの 2 修道院、ならびにヴォロネッツ 旧修道院において「現行の事業を今日の精神にもとづく手法によっ て強調する」注 24)、寸なわち現代風の設計手法をもって修復事業に あたったことが明記されている点である。その役割を一身に担った のが修復建築家イオアナ・グリゴレスク注 25) である。彼女の担当し た 3 案件だけでスチャヴァ県の 7 割以上の事業費が充当されている (全国総事業費の $11.0 \%$ )。

2006 年に亡くなる前に研究者らによって同氏のインタビューを 行い、同時に図面の提供を受けたので、ここで改めて分析する。残 された図面類は、上記 3 修道院以外にセク、シハストリア修道院、 宮殿、古代ローマ遺跡などの修復案件が加わり、種別としては配置 図、平面図、断面図等に加えてスケッチや詳細図など多岐に及ぶ。 ドラゴミルナ修道院の図面をみると明らかに修理図面ではなく、 新規計画図となっている。主体施設である聖堂、ならびに囲壁につ いては保存すべきオセンティックな建造物として留保し、付属施設 たる僧房は新規の建造物として新たにデザインする。鉄筋コンクリ 一トを用い、伝統に想を得ながらも新しい手法を試みた。さらに井 戸や四阿など付属工作物の図面も、モルドヴァの木造建築を敷衍し 
Table 1 Conservation Restoration Projects in Romania in the 1960's, edited from the budgetary table in "Bultinul Monumentelor Istorice", Anul XXXIX, Nr.1, 1970

\begin{tabular}{|c|c|c|c|c|}
\hline County & Site & $\begin{array}{l}\text { Building } \\
\text { Category }\end{array}$ & Year & $\begin{array}{l}\text { Operation } \\
\text { Cost (lei) }\end{array}$ \\
\hline \multirow{4}{*}{$\begin{array}{l}\text { Bucreşti } \\
\text { Municipality }\end{array}$} & Patriarchate & $\begin{array}{l}\text { Romanian } \\
\text { Orthodox }\end{array}$ & $1960-1963$ & $1,452,698$ \\
\hline & $\begin{array}{l}\text { Sf. Troiță Monastery } \\
\text { - Radu Vodă - }\end{array}$ & $\begin{array}{l}\text { Romanian } \\
\text { Orthodox }\end{array}$ & $1962-1969$ & $1,321,462$ \\
\hline & $\begin{array}{l}\text { Casa Enăchiță } \\
\text { Văcărescu }\end{array}$ & House & 1963-1966 & $2,453,998$ \\
\hline & Mărcuța Monastery & $\begin{array}{l}\text { Romanian } \\
\text { Orthodox }\end{array}$ & 1967-1969 & 537,039 \\
\hline \multirow{7}{*}{ Alba } & $\begin{array}{l}\text { Feudal Complex of } \\
\text { Sebeş City }\end{array}$ & $\begin{array}{l}\text { Urban } \\
\text { Complex }\end{array}$ & 1960-1969 & $4,002,971$ \\
\hline & $\begin{array}{l}\text { Village Fortress } \\
\text { with Romanesque } \\
\text { Church in Cricău }\end{array}$ & Reformed & $\begin{array}{c}1961 \\
1964-1967\end{array}$ & $1,089,394$ \\
\hline & Cîlnic Fortress & Evangelical & 1961-1964 & $1,058,187$ \\
\hline & Alba Iulia Fortress & $\begin{array}{l}\text { Fortress/ } \\
\text { Castle }\end{array}$ & $1961-1964$ & 417,940 \\
\hline & $\begin{array}{l}\text { Ruin of the Romanic } \\
\text { Church in Gîrbova }\end{array}$ & $\begin{array}{l}\text { Religious, } \\
\text { Ruin }\end{array}$ & 1966 & 97,181 \\
\hline & $\begin{array}{l}\text { Alba Iulia Orthodox } \\
\text { Cathedral } \\
\text { - a Reîntregirii - }\end{array}$ & $\begin{array}{l}\text { Romanian } \\
\text { Orthodox }\end{array}$ & 1967-1969 & $2,153,835$ \\
\hline & $\begin{array}{l}\text { Alba Iulia Roman } \\
\text { Catholic Cathedral }\end{array}$ & $\begin{array}{l}\text { Roman } \\
\text { Catholic }\end{array}$ & 1967-1969 & $1,317,870$ \\
\hline \multirow{5}{*}{ Argeş } & $\begin{array}{l}\text { Bărătia Ensemble } \\
\text { at Cîmpulung }\end{array}$ & $\begin{array}{l}\text { Roman } \\
\text { Catholic } \\
\end{array}$ & 1963-1965 & $1,636,082$ \\
\hline & $\begin{array}{l}\text { Sf.Gheorghe Church } \\
\text { at Piteşti }\end{array}$ & $\begin{array}{l}\text { Romanian } \\
\text { Orthodox }\end{array}$ & 1963-1968 & $1,237,999$ \\
\hline & $\begin{array}{l}\text { Episcopal Church } \\
\text { at Curtea de Argeş }\end{array}$ & $\begin{array}{l}\text { Romanian } \\
\text { Orthodox }\end{array}$ & 1964-1968 & $1,312,157$ \\
\hline & Brădet Skete & $\begin{array}{l}\text { Romanian } \\
\text { Orthodox }\end{array}$ & 1964-1966 & 543,146 \\
\hline & $\begin{array}{l}\text { Aninoasa } \\
\text { Monastery } \\
\end{array}$ & $\begin{array}{l}\text { Romanian } \\
\text { Orthodox }\end{array}$ & $1968-1969$ & 288,649 \\
\hline \multirow[t]{2}{*}{ Bihor } & $\begin{array}{l}\text { Roman Catholic } \\
\text { Cathedral at } \\
\text { Oradea } \\
\end{array}$ & $\begin{array}{l}\text { Roman } \\
\text { Catholic }\end{array}$ & 1960-1963 & 880,407 \\
\hline & $\begin{array}{l}\text { Wood Church at } \\
\text { Delurenii in Beznea }\end{array}$ & $\begin{array}{l}\text { Romanian } \\
\text { Orthodox }\end{array}$ & 1964-1965 & 167,173 \\
\hline \begin{tabular}{|l|} 
Bistrița \\
Năsăud \\
\end{tabular} & $\begin{array}{l}\text { Wood Church at } \\
\text { Chiraleş } \\
\end{array}$ & $\begin{array}{l}\text { Romanian } \\
\text { Orthodox } \\
\end{array}$ & 1963-1964 & 153,777 \\
\hline Botoşani & $\begin{array}{l}\text { Wood Church } \\
\text { Sf. Dumitru at } \\
\text { Vorniceni }\end{array}$ & $\begin{array}{l}\text { Romanian } \\
\text { Orthodox }\end{array}$ & 1968 & 40,841 \\
\hline \multirow{5}{*}{ Braşov } & $\begin{array}{l}\text { Village Fortress } \\
\text { with Evangelical } \\
\text { Church at Prejmer }\end{array}$ & Evangelical & $1960-1969$ & $5,972,632$ \\
\hline & $\begin{array}{l}\text { Old Hall (Casa } \\
\text { Hirscher) at Braşov }\end{array}$ & House & 1960-1961 & $1,462,669$ \\
\hline & Făgăraş Citadel & $\begin{array}{l}\text { Fortress/ } \\
\text { Castle }\end{array}$ & $1965-1969$ & $11,719,906$ \\
\hline & $\begin{array}{l}\text { Emsemble of } \\
\text { Sf. Nicolae Church } \\
\text { at Șcheii Braşov }\end{array}$ & $\begin{array}{l}\text { Romanian } \\
\text { Orthodox }\end{array}$ & 1968-1969 & 458,089 \\
\hline & $\begin{array}{l}\text { Neagră (Black) } \\
\text { Church at Braşov } \\
\end{array}$ & Evangelical & $1968-1969$ & 189,772 \\
\hline \multirow{4}{*}{ Cluj } & $\begin{array}{l}\text { Reformed Church } \\
\text { at Cluj }\end{array}$ & Reformed & 1960 & 327,534 \\
\hline & $\begin{array}{l}\text { Roman Catholic } \\
\text { Church Sf. Mihail } \\
\text { at Cluj }\end{array}$ & $\begin{array}{l}\text { Roman } \\
\text { Catholic }\end{array}$ & $1960-1964$ & $2,527,130$ \\
\hline & $\begin{array}{l}\text { Roman Catholic } \\
\text { Church at Floreşti }\end{array}$ & $\begin{array}{l}\text { Roman } \\
\text { Catholic }\end{array}$ & $1961-1963$ & 581,686 \\
\hline & Fortress at Dăbîca & $\begin{array}{l}\text { Fortress/ } \\
\text { Castle }\end{array}$ & 1969 & 150,000 \\
\hline \multirow{4}{*}{ Constanța } & $\begin{array}{l}\text { Roman Ensemble } \\
\text { with Mosaic at } \\
\text { Constanța } \\
\end{array}$ & Antiquity & $1960-1969$ & $10,981,769$ \\
\hline & $\begin{array}{l}\text { Antic Grave at } \\
\text { Mangalia }\end{array}$ & Antiquity & 1960 & 518,854 \\
\hline & Mosque at Mangalia & Muslim & 1960-1962 & 416,880 \\
\hline & $\begin{array}{l}\text { Triumphal } \\
\text { Monument and } \\
\text { Municipium } \\
\text { Tropaeum Trajani } \\
\text { at Adamclisi } \\
\end{array}$ & Antiquity & $1960-1969$ & $1,717,907$ \\
\hline
\end{tabular}

\begin{tabular}{|c|c|c|c|c|}
\hline County & Site & $\begin{array}{l}\text { Building } \\
\text { Category }\end{array}$ & Year & $\begin{array}{c}\text { Operation } \\
\text { Cost (lei) }\end{array}$ \\
\hline Constanța & $\begin{array}{l}\text { Rock-hewn } \\
\text { Ensemble Besarabi } \\
\text { at Mulfatlar }\end{array}$ & $\begin{array}{l}\text { Religious, } \\
\text { Ruin }\end{array}$ & 1960-1969 & $2,505,602$ \\
\hline \multirow{2}{*}{ Dîmbovița } & $\begin{array}{l}\text { Princely Court at } \\
\text { Tîrgovişte }\end{array}$ & Palace & 1961-1969 & $4,788,359$ \\
\hline & $\begin{array}{l}\text { Sf. Vineri Church at } \\
\text { Tîrgovişte }\end{array}$ & $\begin{array}{l}\text { Romanian } \\
\text { Orthodox }\end{array}$ & 1968-1969 & 794,436 \\
\hline Gorj & Tismana Monastery & $\begin{array}{l}\text { Romanian } \\
\text { Orthodox }\end{array}$ & $\begin{array}{c}1960 \\
1968-1969\end{array}$ & 260,344 \\
\hline \multirow{2}{*}{ Hunedoara } & $\begin{array}{l}\text { Sf.Nicolae at } \\
\text { Densuş }\end{array}$ & $\begin{array}{l}\text { Romanian } \\
\text { Orthodox }\end{array}$ & N/A & 263,963 \\
\hline & $\begin{array}{l}\text { Corvineştilor Castle } \\
\text { at Hunedoara }\end{array}$ & $\begin{array}{l}\text { Fortress/ } \\
\text { Castle }\end{array}$ & $1965-1969$ & $5,324,778$ \\
\hline \multirow{12}{*}{ Iaşi } & $\begin{array}{l}\text { Trei Ierarhi Church } \\
\text { and Gothic Hall in } \\
\text { Iaşi }\end{array}$ & $\begin{array}{l}\text { Romanian } \\
\text { Orthodox }\end{array}$ & $\begin{array}{c}1960 \\
1961-1963 \\
1968\end{array}$ & $1,244,779$ \\
\hline & $\begin{array}{l}\text { Metropolitan } \\
\text { Cathedral of Iaşi }\end{array}$ & $\begin{array}{l}\text { Romanian } \\
\text { Orthodox }\end{array}$ & 1960 & 144,586 \\
\hline & $\begin{array}{l}\text { Dosftei's Printing } \\
\text { House }\end{array}$ & House & $\begin{array}{c}1960 \\
1967-1969 \\
\end{array}$ & 732,639 \\
\hline & $\begin{array}{l}\text { Galata Monastery } \\
\text { at Iaşi }\end{array}$ & $\begin{array}{l}\text { Romanian } \\
\text { Orthodox }\end{array}$ & 1961-1969 & $3,935,109$ \\
\hline & $\begin{array}{l}\text { Cetățuia Monastery } \\
\text { at Iaşi }\end{array}$ & $\begin{array}{l}\text { Romanian } \\
\text { Orthodox }\end{array}$ & 1964-1969 & $2,041,100$ \\
\hline & $\begin{array}{l}\text { Barnovski Church } \\
\text { at Iaşi }\end{array}$ & $\begin{array}{l}\text { Romanian } \\
\text { Orthodox }\end{array}$ & 1968 & 68,920 \\
\hline & $\begin{array}{l}\text { Sf. Dumitru Church } \\
\text { at Hîrlău }\end{array}$ & $\begin{array}{l}\text { Romanian } \\
\text { Orthodox }\end{array}$ & 1968 & 45,781 \\
\hline & $\begin{array}{l}\text { Bîrnova Monastery } \\
\text { at Iaşi }\end{array}$ & $\begin{array}{l}\text { Romanian } \\
\text { Orthodox }\end{array}$ & 1968-1969 & 74,278 \\
\hline & $\begin{array}{l}\text { Sf. Spiridon Church } \\
\text { at Iaşi }\end{array}$ & $\begin{array}{l}\text { Romanian } \\
\text { Orthodox }\end{array}$ & 1968 & 94,929 \\
\hline & $\begin{array}{l}\text { Sf. Apostoli-Borboi } \\
\text { at Iaşi }\end{array}$ & $\begin{array}{l}\text { Romanian } \\
\text { Orthodox }\end{array}$ & 1968 & 62,383 \\
\hline & $\begin{array}{l}\text { Frumoasa } \\
\text { Monastery at Iaşi }\end{array}$ & $\begin{array}{l}\text { Romanian } \\
\text { Orthodox }\end{array}$ & 1968 & 17,971 \\
\hline & $\begin{array}{l}\text { Sf. Ion cel Nou } \\
\text { Church - Nicorița - } \\
\text { at Iaşi }\end{array}$ & $\begin{array}{l}\text { Romanian } \\
\text { Orthodox }\end{array}$ & 1968 & 140,513 \\
\hline \multirow{3}{*}{ Ilfov } & $\begin{array}{l}\text { Balamuci Skete at } \\
\text { Balta Naegră in } \\
\text { Nuci }\end{array}$ & $\begin{array}{l}\text { Romanian } \\
\text { Orthodox }\end{array}$ & 1960-1962 & 440,944 \\
\hline & $\begin{array}{l}\text { Căldăruşani } \\
\text { Monastery in Brazil }\end{array}$ & $\begin{array}{l}\text { Romanian } \\
\text { Orthodox }\end{array}$ & 1960-1964 & 667,736 \\
\hline & \begin{tabular}{|l|} 
Casa Udrişte \\
Năsturel at Hereşti
\end{tabular} & House & 1964-1969 & $2,089,256$ \\
\hline \multirow[b]{2}{*}{ Maramureş } & $\begin{array}{l}\text { Wood Church } \\
\text { Sf. Arhangheli at } \\
\text { Plopiş in Şişessti and } \\
\text { Wood Church } \\
\text { Sf. Arhangheli at } \\
\text { Remetea Chioarului } \\
\end{array}$ & $\begin{array}{l}\text { Romanian } \\
\text { Orthodox }\end{array}$ & 1960-1961 & 533,487 \\
\hline & $\begin{array}{l}\text { Wood Church "Din } \\
\text { deal" at Ieud, Wood } \\
\text { Church "Din vale" } \\
\text { at Ieud, Wood } \\
\text { Church Cuvioasa } \\
\text { Paraschiva at } \\
\text { Botiza and Wood } \\
\text { Church at Poienile } \\
\text { Glodului }\end{array}$ & $\begin{array}{l}\text { Romanian } \\
\text { Orthodox }\end{array}$ & 1961-1962 & 702,689 \\
\hline \multirow{3}{*}{ Mehedinți } & $\begin{array}{l}\text { Drobeta Castle at } \\
\text { Turnu Severin }\end{array}$ & $\begin{array}{l}\text { Fortress/ } \\
\text { Castle }\end{array}$ & 1960-1963 & 605,507 \\
\hline & Strehaia Monastery & $\begin{array}{l}\text { Romanian } \\
\text { Orthodox }\end{array}$ & 1963-1969 & $1,648,179$ \\
\hline & $\begin{array}{l}\text { Strămutarea } \\
\text { Monument at } \\
\text { Porțile de Fier } \\
\end{array}$ & $\begin{array}{l}\text { Urban } \\
\text { Complex }\end{array}$ & $1967-1969$ & $11,720,440$ \\
\hline \multirow{2}{*}{ Mureş } & $\begin{array}{l}\text { City Fortress } \\
\text { Tg. Mureş with } \\
\text { Reformer Church }\end{array}$ & Reformed & 1963-1969 & $4,460,064$ \\
\hline & $\begin{array}{l}\text { Wood Church } \\
\text { Sf.Arhangheli at } \\
\text { Chețani }\end{array}$ & $\begin{array}{l}\text { Romanian } \\
\text { Orthodox }\end{array}$ & 1967-1968 & 200,767 \\
\hline \multirow{2}{*}{ Neamț } & Neamț Monastery & $\begin{array}{l}\text { Romanian } \\
\text { Orthodox }\end{array}$ & $\begin{array}{c}1960-1961 \\
1963,1968\end{array}$ & $3,959,276$ \\
\hline & Agapia Monastery & $\begin{array}{l}\text { Romanian } \\
\text { Orthodox }\end{array}$ & $\begin{array}{c}1961-1962 \\
1968\end{array}$ & 722,477 \\
\hline
\end{tabular}




\begin{tabular}{|c|c|c|c|c|}
\hline County & Site & $\begin{array}{l}\text { Building } \\
\text { Category }\end{array}$ & Year & $\begin{array}{l}\text { Operation } \\
\text { Cost (lei) }\end{array}$ \\
\hline \multirow{4}{*}{ Neamț } & Neamț Fortress & $\begin{array}{l}\text { Fortress/ } \\
\text { Castle }\end{array}$ & $1963-1969$ & $3,841,411$ \\
\hline & Secu Monastery & $\begin{array}{l}\text { Romanian } \\
\text { Orthodox }\end{array}$ & $1966-1969$ & $1,952,851$ \\
\hline & Văratec Monastery & $\begin{array}{l}\text { Romanian } \\
\text { Orthodox }\end{array}$ & 1968 & 120,936 \\
\hline & Bistrița Monastery & $\begin{array}{l}\text { Romanian } \\
\text { Orthodox }\end{array}$ & 1969 & 320,000 \\
\hline Olt & Căluiu Monastery & $\begin{array}{l}\text { Romanian } \\
\text { Orthodox }\end{array}$ & $1967-1969$ & 254,489 \\
\hline Prahova & Brebu Monastery & $\begin{array}{l}\text { Romanian } \\
\text { Orthodox }\end{array}$ & 1960, 1963 & 995,764 \\
\hline \multirow[b]{3}{*}{ Sălaj } & $\begin{array}{l}\text { Wood Church at } \\
\text { Petrindu Mare }\end{array}$ & $\begin{array}{l}\text { Romanian } \\
\text { Orthodox }\end{array}$ & $1965-1966$ & 287,673 \\
\hline & $\begin{array}{l}\text { Wood Church at } \\
\text { Cizer }\end{array}$ & $\begin{array}{l}\text { Romanian } \\
\text { Orthodox }\end{array}$ & $1967-1968$ & 290,010 \\
\hline & $\begin{array}{l}\text { Wood Church Sf. } \\
\text { Arhangheli at Baica } \\
\text { in Hida, Wood } \\
\text { Church Sf. } \\
\text { Arhangheli at } \\
\text { Poarta Sălajului in } \\
\text { Românași }\end{array}$ & $\begin{array}{l}\text { Romanian } \\
\text { Orthodox }\end{array}$ & 1969 & 180,000 \\
\hline \multirow{4}{*}{ Sibiu } & $\begin{array}{l}\text { Ruined Cistercian } \\
\text { Monastery at Cîrța }\end{array}$ & $\begin{array}{l}\text { Religious, } \\
\text { Ruin }\end{array}$ & 1961-1962 & 116,622 \\
\hline & $\begin{array}{l}\text { Sfantului Tower at } \\
\text { Sibiu }\end{array}$ & Antiquity & $1961-1962$ & 296,804 \\
\hline & $\begin{array}{l}\text { Fortress with } \\
\text { Romanesque } \\
\text { Church Sf.Mihail at } \\
\text { Cisnădioara } \\
\end{array}$ & $\begin{array}{l}\text { Roman } \\
\text { Catholic }\end{array}$ & 1961-1962 & 799,320 \\
\hline & $\begin{array}{l}\text { Old City Hall of } \\
\text { Sibiu }\end{array}$ & House & $1967-1969$ & 577,133 \\
\hline \multirow{3}{*}{ Suceava } & Sucevița Monastery & $\begin{array}{l}\text { Romanian } \\
\text { Orthodox }\end{array}$ & 1960-1969 & $8,964,423$ \\
\hline & Humor Monastery & $\begin{array}{l}\text { Romanian } \\
\text { Orthodox }\end{array}$ & $\begin{array}{l}1960-1961 \\
1967-1969\end{array}$ & 428,707 \\
\hline & Salatina Monastery & $\begin{array}{l}\text { Romanian } \\
\text { Orthodox }\end{array}$ & $\begin{array}{l}1960-1961 \\
1968-1969 \\
\end{array}$ & 653,831 \\
\hline
\end{tabular}

\begin{tabular}{|c|c|c|c|c|}
\hline County & Site & $\begin{array}{l}\text { Building } \\
\text { Category }\end{array}$ & Year & $\begin{array}{l}\text { Operation } \\
\text { Cost (lei) }\end{array}$ \\
\hline \multirow{12}{*}{ Suceava } & $\begin{array}{l}\text { Former Voroneț } \\
\text { Monastery }\end{array}$ & $\begin{array}{l}\text { Romanian } \\
\text { Orthodox }\end{array}$ & $\begin{array}{c}1961-1968 \\
1969\end{array}$ & $1,650,221$ \\
\hline & $\begin{array}{l}\text { Dragomirna } \\
\text { Monastery }\end{array}$ & $\begin{array}{l}\text { Romanian } \\
\text { Orthodox }\end{array}$ & $1961-1969$ & $6,567,460$ \\
\hline & $\begin{array}{l}\text { Scaun Fortress at } \\
\text { Suceava }\end{array}$ & $\begin{array}{l}\text { Fortress/ } \\
\text { Castle }\end{array}$ & 1961-1969 & $2,291,422$ \\
\hline & $\begin{array}{l}\text { Princely Han at } \\
\text { Suceava }\end{array}$ & Palace & 1964-1967 & $1,216,543$ \\
\hline & $\begin{array}{l}\text { Church of the } \\
\text { Beheading of St } \\
\text { Ioan Botezătorul of } \\
\text { Arbore }\end{array}$ & $\begin{array}{l}\text { Romanian } \\
\text { Orthodox }\end{array}$ & 1964-1968 & 668,971 \\
\hline & $\begin{array}{l}\text { Moldovița } \\
\text { Monastery }\end{array}$ & $\begin{array}{l}\text { Romanian } \\
\text { Orthodox }\end{array}$ & $1965-1969$ & $1,352,139$ \\
\hline & Putna Monastery & $\begin{array}{l}\text { Romanian } \\
\text { Orthodox }\end{array}$ & $1968-1969$ & 360,608 \\
\hline & Rîşca Monastery & $\begin{array}{l}\text { Romanian } \\
\text { Orthodox }\end{array}$ & 1968 & 118,991 \\
\hline & Probota Monastery & $\begin{array}{l}\text { Romanian } \\
\text { Orthodox }\end{array}$ & 1968 & 30,735 \\
\hline & $\begin{array}{l}\text { Sf. Nicolae at } \\
\text { Bălineşti in } \\
\text { Grămeşti }\end{array}$ & $\begin{array}{l}\text { Romanian } \\
\text { Orthodox }\end{array}$ & 1968 & 113,249 \\
\hline & $\begin{array}{l}\text { Wood Church } \\
\text { Sf. Nicolae at } \\
\text { Broşteni }\end{array}$ & $\begin{array}{l}\text { Romanian } \\
\text { Orthodox }\end{array}$ & 1968 & 67,784 \\
\hline & Coşula Monastery & $\begin{array}{l}\text { Romanian } \\
\text { Orthodox }\end{array}$ & 1968 & 30,400 \\
\hline Tulcea & $\begin{array}{l}\text { Cocoş Monastery at } \\
\text { Niculițel }\end{array}$ & $\begin{array}{l}\text { Romanian } \\
\text { Orthodox }\end{array}$ & 1960 & 54,088 \\
\hline \multirow{3}{*}{ Vîlcea } & Cozia Monastery & $\begin{array}{l}\text { Romanian } \\
\text { Orthodox }\end{array}$ & 1960-1962 & $1,020,265$ \\
\hline & Cornet Monastery & $\begin{array}{l}\text { Romanian } \\
\text { Orthodox }\end{array}$ & 1960 & 232,785 \\
\hline & Hurezi Monastery & $\begin{array}{l}\text { Romanian } \\
\text { Orthodox }\end{array}$ & $1960-1969$ & $10,454,993$ \\
\hline
\end{tabular}

$※$ Except cases of "Urgent Intervention" and "Restoration for the Installation of Electricity in Interior" from the original list.

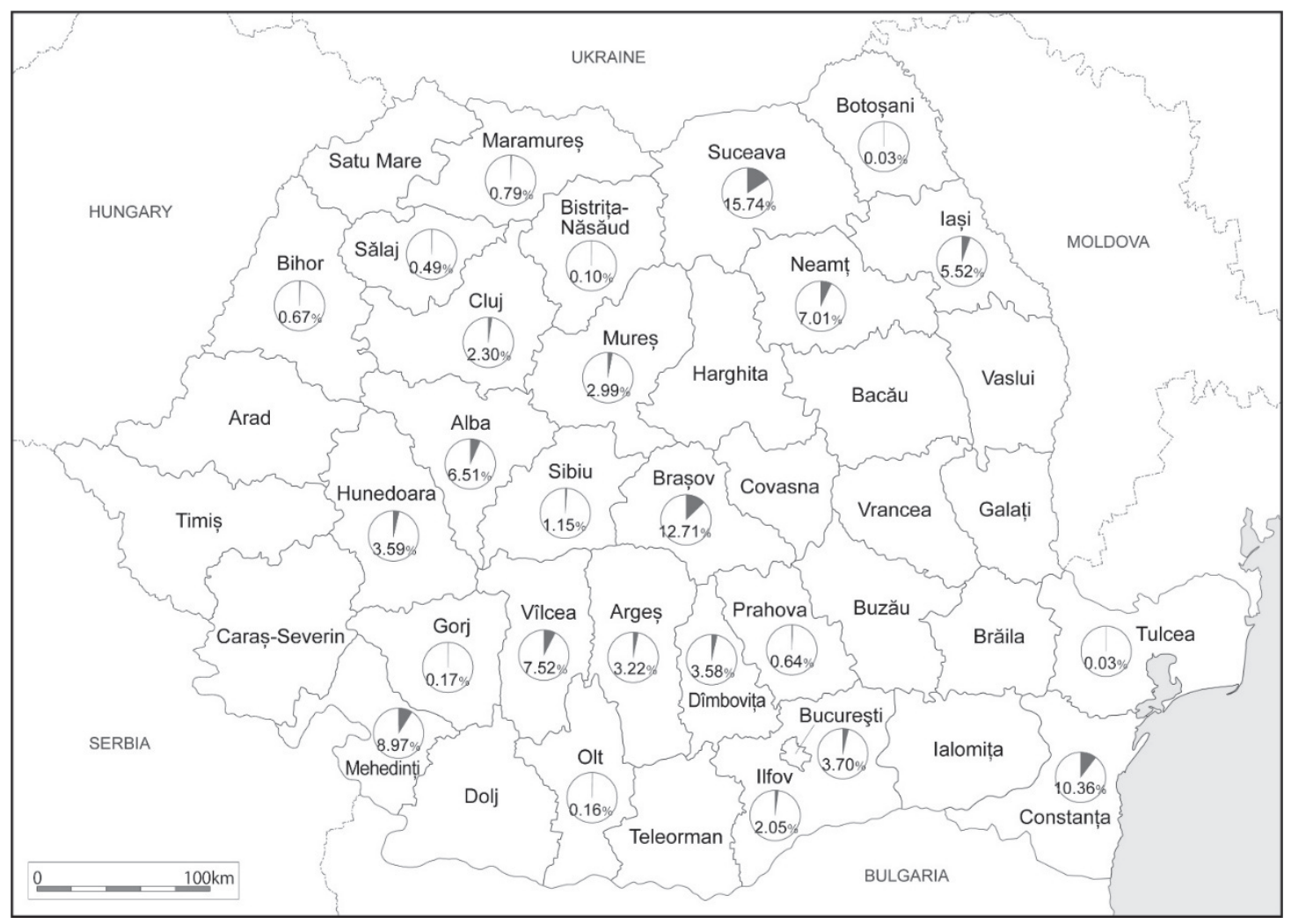

Fig.1 Administrative Map of Romania by County, 1968

The pie chart shows the percent of each prefecture's expense to national total regarding Conservation Restoration Projects in Romania in the 1960's (Table 1) 
た意匠で、全体のデザイン・ポリシーを補完している。

1960 年代前半に始められたこれらの修復事業は、当時の文化状況 を反映してルーマニア固有の価值観や美学を表すことが求められた。 ルーマニアの伝統デザインを極めながら高度の造形性を示寸彼女の デザインは局幹部の関心を惹き、バルシュの後継者としてのポジシ ヨンを得る。生前の彼女からの聞き取りや残された図面からその一 端を伺うことができる（Fig.2）。彼女の振り当てられた多大の予算 は、ルーマニアの歴史遺産の顔となるよう、当初建築の修復に加え て新たなデザインの僧房・展示室等の建設に充てられた。

\section{7. 正教会の役割}

正教会にとってスチャヴァ一帯は摇籃の地と見なされるが、当時、 この地で修道院として機能していたのは、プトナ、スチェヴィツァ、 モルドヴィツァ、ドラゴミルナの 4 修道院のみで、他はこの地を第 一次大戦期まで統治していたオーストリア＝ハンガリー帝国による 世俗化政策によって 19 世紀後半に閉鎖されていた。この点は、保 存修復事業を推し進める歴史的記念物局にとって逆説的にプラスに 働き、修道院ならびにそれを管轄するスチャヴァ大主教座との面倒 な手続きを経ることなく工事を進めることができた。この時期の遺 産保護はリベラルな環境の中で「共産党の追い求めるイデオロギー や目標とはまったく関係ないところでその事業が行われていた」た め、王政時代よりもスムーズに進んだとまで言われている注 26)。

歴史的記念物局にとって追い風となったのは、1967 年に国連によ って大々的になされた国際観光年キャンペーンであった。歴史文化 遺産はルーマニアの観光資源としての価值を付与され、地域ごとに 特徵的な遺産群が抽出される。フレスコ画で内外壁を埋め尽くした モルドヴァの修道院群、マラ・ムレシュの木造教会群、トランシル ヴァニアの福音派(ルター派)のゴシック聖堂群などが選び出され、 保存修復のための予算枠が拡大される。この年の観光客は微増に留 まり、観光年としてのプロモーションは必ずしも成功とはいえない が、遺産保護に弾みがついたという点ではその後に与えた影響は大 きかった。グリゴレスクが担当した中世修道院は、国賓クラスの接 待施設として利用され、実際に 1979 年にはヴオロネッツ旧修道院 に日本の皇太子・皇太子妃夫妻（当時）が招待されている注 27 ）

グリゴレスクは 1972 年に定年となった以降は活躍の場を失い、 実質的に修復事業から引退した。彼女のアイデアはその後、継承さ れることなく、保存修復事業におけるこの種の大型案件がなくなる が、時期的にはチャウシェスクの新たな文化政策に対応している。

\section{3. 歴史都市の再編問題}

\section{1. 国土体系化政策}

社会主義期のルーマニアの国土計画・都市計画を語る際、西欧型 の都市整備の枠組みを「科学的」かつイデオロギー的に組み直した 「体系化」(sistematizarea) なる概念が用いられている点に注目し たい注 28)。建設省にあたる国家委員会（建設・建築・国土体系化国 家委員会）の名称にもこの用語が冠せられる。この用語自体は、古 い都市を整備して新たな都市空間をつくり出すという意味で 1920 年代から「都市計画」を指して用いられていたが、社会主義政権に よって包括的な国土計画のスケールに拡大解釈され、社会主義国家 のイデオロギーに読み替えられる。具体的には、 5 か年計画をべー スとして産業、インフラ、居住基盤を繋いだネットワークを下敷き として国土の「体系化」をめざし、とりわけ国の近代化を妨げてい る農業依存型の経済を第二次・第三次産業型にシフトさせるべく、 都市化の推進が主眼となる。社会主義政権の成立にともなって 1948 年に土地国有化が宣言され、15 年ほどをかけて山岳部を除く耕作可 能な土地において農業の集団化が実施された。これにより生じた農 村部の余剰労働人口を都市に移住させることが目論まれる。重工業、 特に機械・化学工業のプラントを全国に分散配置し、都市周縁部に おける工業地区開発を行うとともに、オネシュティ（モルドヴァ地 方南部）に代表される村落部の工業都市化に焦点が当てられた。こ のようにして、総人口に対する都市人口比は 1948 年の $23.4 \%$ から 1977 年の $43.6 \%$ へと 30 年間で倍増する注 29$) 。$

チャウシェスクはこの国土政策を徹底させることを目論み、その 手始めとして 1972 年に国土体系化のための包括的なプログラムを 発布する。その基本は経済基盤の構築を目的とした人口増加施策の 推進にあり、生産拠点としての都市ネットワークの拡充をめざした。 そのため、人口 1 万人以上とされる「市」（oraș）に加えて、各県で 重点的にいくつかの「村」(comună) を選定し、生産施設等を配備 した人口 5000 人程度の町をつくり、染意的に市制を適用するとい うものである注 ${ }^{30)}$ 。そのプログラムの法的根拠となるのが 1974 年の 「地域ならびに都市・農村集落の体系化に関する立法、第 58」注31) で、その後の四半世紀の間に全国で相当数の小規模都市整備を行う ことが定められた。そこから外れた農村部の集落に対しても、公共 施設をともない歴史遺産を重んじた施策を打ち出している注 32 。

国土ネットワークを、従来の数十ほどの歴史的中核都市による単 一ネットワークから地域ごとの新都市サブグループをともなった複
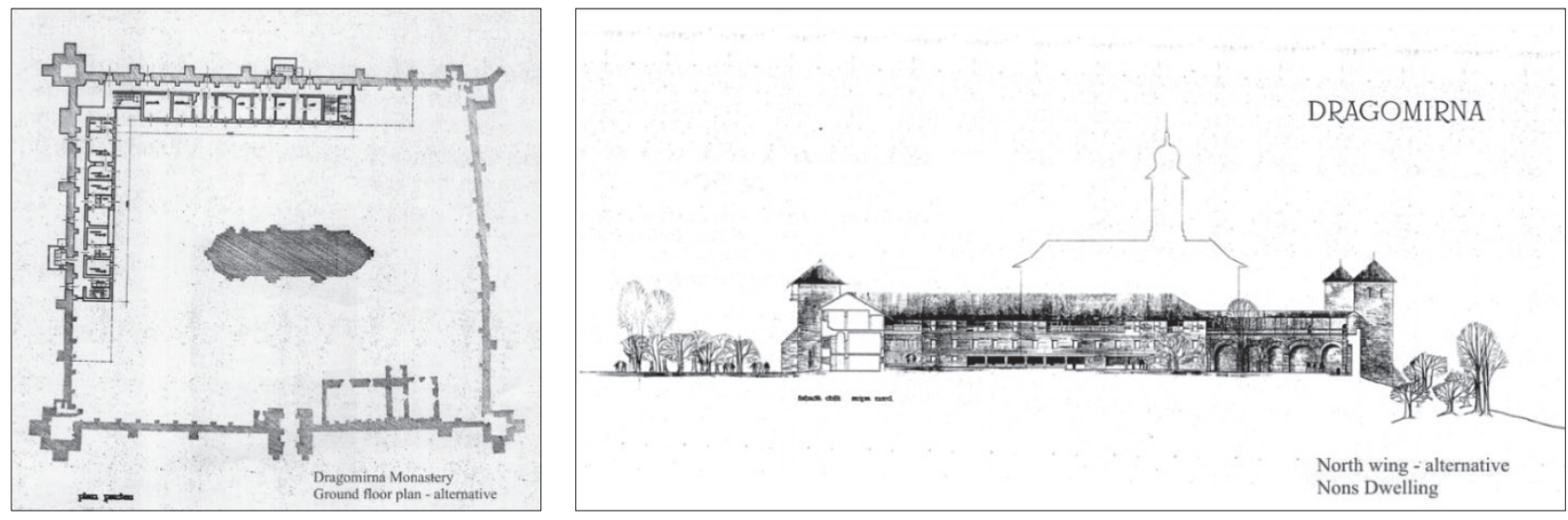

Fig.2 Drawings of Dragomirna Monastery by loana Grigorescu (left: Site Plan, right: Section), s.d., Grigorescu Own Collection 
合ネットワークに変換するという大胆な試みであるが、これらを全 面的に実現に移すための財政基盤を欠き、喫緊の課題である都市化 が優先的に実施対象となった。その結果、1971 年から 5 年間で 340 の集落が選ばれ、コンパクトな集合住宅地と生産施設をともなった 小規模新都市の計画がなされる注 ${ }^{33)}$ 。逆に集団化の対象となった農 村部は、都市部への人口移動が進み、生産性がさらに落ちた結果、 衰退の兆しが顕著となる。

\section{2. 歴史都市と中心市街地}

1970 年代に入って、国土体系化政策は既存の都市の都市計画に及 ぶようになる注 ${ }^{34)}$ 。ルーマニアの都市は、人口 180 万人 (1977 年) を数える首都ブカレストに対して他の都市の人口は数万から 30 万 人程度であったが、長い歴史文化に裏付けられたものが多い。とり わけモルドヴァとトランシルヴァニアはその点が顥著であり、当初 は農村部が多くを占める南部のムンテニアやオルテニアに向けられ ていた国土体系化の枠組みからは外れていた。

歴史都市の問題は 1970 年代に入って識者たちの間で強く意識さ れるようになり、その点ではフランス、ドイッなど西欧諸国の都市 保存の議論と時間的な隔たりはあまりない。実際、リベラルな気風 をもつ歴史的記念物局（DMI）は 1970 年代初頭になってブカレス トを筆頭にクライオヴァ、ブライラ、コンスタンツァ、スチャヴァ など 25 都市を歴史的都市として認定している。1960 年代に歴史的 記念物局長を務めたグリゴーレ・イオネスク注 ${ }^{35)}$ が同局の公式媒体 でもある『歴史的記念物紀要』(Buletinul Monumentelor Istorice) 誌上で「体系化」の用語を用いつつ、ユネスコの歴史地区保護の施 策を下敷きにシビウ、クルージュ、ブラショヴなどトランシルヴァ ニアの歴史都市の重要性を指摘していることを見れば、当初議論さ れていた国土体系化の理念は 1970 年代後半に入って顕著となる歴 史性排除の施策とは位相を異にしていたことが理解できよう注36)。

こうした 1970 年代前半の歴史都市保護の機運はそのまま国際機 関や西欧諸国の動きと連動し、とりわけ 1975 年の欧州建築遺産年 に対しては歴史的記念物局を挙げて関与し、ユネスコやイコモスの 活動に積極的に参画し、国際基準の導入に務める。同時に、グリゴ レスクによって「修復」されたいくつかの修道院が、大きな役割を もって発信されている。その一方で、1974 年の国土体系化法により、 都市部の詳細計画の作成が義務付けられ、歷史地区をめぐって再開 発に対する判断が迫られるようになる。

この動きに決定的な影響を与えたのが、1975 年 7 月初めにルー マニア南部を襲った観測史上最大の洪水であり注 37$) 、 2$ 年後の 1977 年 3 月 4 日にブカレスト一帯を襲ったヴランチャ地震である注 38 。 特に後者の地震は、全壊・半壊を含めてルーマニアの住戸総数の $13 \%$ に被害を与えるというきわめて深刻な事態をもたらし、震災復 興が何よりも大きな課題としてのしかかった。それまで歴史的環境 に宥和的な姿勢を見せていたチャウシェスク政権が再開発を主眼と した都市改造に舵を切るのもこの地震を契機としてであった。歴史 遺産を統括する歴史的記念物局も同年、経済文化遺産局（Direcția Economica și Patrimoniului Cultural Național $=\mathrm{DEPCN})$ と改 組され、遺産保護の考え方自体が国土体系化政策の中に包摂される と同時に予算、人員面で大幅な削減にあう。

\section{4. 考察 社会主義政権における文化遺産の諸問題}

\section{1. チャウシェスク政権前期の体系化と文化遺産政策}

ルーマニアの社会主義政権の地域政策を一言で表すのが「体系化」 なる用語であるが、本来、この語は都市計画を指す専門用語として 1930 年代から用いられていた。社会主義政権になってマルクス主義 的な解釈が上乗せされ、科学的かつトップダウン的な計画理論とし て把握されるようになり、共産党委員会の下で国内の産業構造の転 換や都市化を重点的な政策課題として国土全体の体系化が図られる。 その結果、単一規格のインフラ、標準仕様の集合住宅等によって都 市の均質化が促進され、地域ごとに豊かな歴史遺産を擁していた地 方都市の脱歴史化が進展する。ただ、文化政策という視点で眺めた 場合、必ずしもソ連型の画一主義ではなく、ルーマニア独自の造形 や表現にこだわり、その文化的アイデンティティの追求に多大の予 算と専門家が振り向けられた。グリゴレスクのような力ある建築家 が登用されたのが、その証しである。

時として独裁的な権力を行使したチャウシェスクの文化政策の基 盤にあったのは「ホモ・ソヴィエティクス」と呼ばれる社会主義的 人間像の創出にあった。民族衣装を被りながらもマスゲームやスポ ーツに興じる若者を想定し、そのヴィジョンを徹底させた上で都市 建設や施設計画、遺産の活用を図ったことで、同時代の東欧社会主 義国家のリーダーの中でも特異な存在である。少なくとも 1977 年 のヴランチャ地震の前において、地方都市に散在する歴史遺産は大 いに活用が見込まれるものであり、国民の $86 \%$ を数える信徒を擁す る正教会との融和を図る上でも教会遺産の視覚化は重要な課題であ った。宗教建築の歴史性を宗教性とは巧みに分離し、教会の関与を 最小限にして歴史的記念物の専門家に保存修復を任せる姿勢は当初、 脱宗教化が進んだ西側諸国や国際機関でも評価されていた。オース トリア＝ハンガリー支配の時期に廃止されたヴオロネッツ修道院を グリゴレスクの手によって修復し国賓接待に用いたように、歴史的 建造物は外交手段としても有効であった。1989 年のルーマニア革命 後、これらの中世修道院がユネスコ世界遺産にすみやかに登録され たのも、この時代の研究や保存修復作業の蓄積があったからに他な らない。

しかし、1970 年代後半になっても社会主義政権特有の硬直した官 僚機構ゆえに体系化の目標值到達には程遠く、しかも増大寸る対外 債務から国の財政事情が悪化したこともあって、文化部門（社会主 義文化教育常務委員会）は大幅な組織改編が迫られる。それまでの 社会主義の広報・教育担当としての文化省の機能が失われ、組織が 縮小されたところにヴランチャ地震が決定的な打撃を与えた。

\section{2. 教会遺産の保存修復}

社会主義時代における教会遺産の保存修復事業を追跡するには、 当事者である正教会の意思と国の歴史的記念物局（DMI）による修 復事業計画の双方を擦り合わせて考えなければならない。政権とル ーマニア正教会との関係は、ソ連式の徹底した宗教弾圧ではなく、 政権側が飴と鞭を使い分けながらさまざまな懐柔策を弄して総主教 座を取り込み、人心掌握のために教会を積極的に利用する方向で動 いていた。その中で歴史遺産を所管する歴史的記念物局は、高度の 専門性ゆえに戦前の王政時代からの遺産保護の流れを引き継ぎ、必 ずしも社会主義イデオロギーに与しない半ば独立した専門機関であ った。ただ、19世紀の世俗化政策の延長線上に神学ではなく近代科 
学で動くという点では、政権のイデオロギーとは別の意味で修道制 の理念と対立する。それでも、多くの中世修道院を擁し人々の信仰 心も篤いモルドヴァ地方に見られるように長年の保存修復事業の蓄 積は、聖職者とそれを支える地元民による教会コミュニティと専門 部局の間で継続的な人的交流を生み出し、資金や資材を臨機応変に やりくりする環境を培った。人々の尊敬を集めていた修復建築家シ ュテファン・バルシュが後に語ったように、「現実にはいろいろと問 題がありましたが、修復事業のある部分は教会（総主教座、府主教 座、主教座）や地元自治体が引き継ぎ、記念物局が提供した人材や 資材を用いてきました。このようにして以前に始まった事業が今日 の新しい計画に繋がっているのです。」注 39)

\section{5. 結語}

20 世紀の政治的変動の中で生み出された東欧の社会主義国家群 の中でもルーマニアは、正教会を基盤とする従来の伝統規範と「ホ モ・ソヴィエティクス」を追求するイデオロギーとのせめぎ合いの 中でルーマニア独自のアイデンティティを強く打ち出した文化政策 を立ち上げる。中世の修道院を中心とする歴史遺産はそれ自体が世 界にアピールする視覚的な装置であり、チャウシェスク政権はむし ろそれらを積極的に活用して国際社会の中で自国のアピールをはか った。少なくとも 1977 年のヴランチャ地震に到るまでのチャウシ エスク政権前期においては、特徴的な教会・修道院の保存活用に加 えて、いかなる教会も原則として「壊さない」ことを基本として地 域社会の安定化をはかり、それゆえにソ連のような徹底した宗教建 築の破壊を免れることができた。その中で、歴史的記念物局とその 周りの専門家集団は第二次大戦前からの遺産保護の思想を継承し、 政権と正教会の間の微妙なバランスをうまく利用して実際の修復案 件を巧みに誘導して壁画修復を含めた中世建築遺産の保護修復の方 法論を立ち上げる。この蓄積が大きく崩れるのは、1977 年以降のチ ヤウシェスク政権後期であるが、その考察は次の論文に譲りたい。

\section{参考文献}

1) Ion Dodu Balan: Cultural Policy in Romania, The UNESCO Press, Paris, 1975

2) Vasile Cucu: Sistematizarea teritoriului şi localităților din România, Editura Ştiințifică şi Enciclopedică, Bucureşti, 1977

3) Olivier Gillet: Religion et nationalism - L'Idéologie de l'Eglise roumaine sous le régime communiste, Edition de l'Université de Bruxelles, 1997

4) Lavinia Stan, Lucian Turcescu: Religion and Politics in Post - Commu -nist Romania, Oxford University Press, Oxford / New York, 2007

5) Riichi Miyake, Shuji Hanyu ed.: World Heritage in Moldavia and its Restoration, Nishimura Shoten, Tokyo, 2009 (in Japanese) 三宅理一・羽生修二監修：モルドヴァの世界遺産とその修復ールーマニア の中世修道院美術と建築，西村書店, 2009

6) Liliana Iuga: Reshaping the Historic City under Socialism - State Preservation, Urban Planning and the Politics of Scarcity in Romania (1945-1977), dissertation, Central European University, Budapest, 2016

7) Florin Abraham: Romania since the Second World War - A Political, Social and Economic History, Bloomsbury Academic, London, Oxford, 2016

8) Bultinul Monumentelor Istorice, bi-annual magazine between 1970 $-1973$

9) Monumente Istorice şi Artă, bi-annual magazine between 1974 -1980

\section{注}

注1）展覧会「中世ルーマニアの文化遺産とヨアナ・グリゴレスクの世界」（於
日本建築学会建築博物館, 2003 年 12 月 $4-26$ 日) が開催され、同氏の図面が 展示された。

注2）ルーマニアの宗教団体はルーマニア正教会（人口の $86 \%$ ) を筆頭にギリ シア・カトリック教会、ローマ・カトリック教会、プロテスタント諸派な どさまざまである。ギリシア・カトリック教会はトランシルヴァニアに多 く、1948年以前は $150-200$ 万人の信徒。1866年（1923年、1938年改訂） の憲法では正教会とギリシア・カトリック教会を「国家教会」として国に よる財政支援、聖職者の給与支給などを保証していたが、1948年の宗教法 改正でギリシア・カトリック教会はそこから外され、正教会に合体して資 産の多くを正教会に譲渡することとなった。その際、正教への改宗を拒ん だ主教、司祭ら600名ほどが投獄された。宗派としてはカトリック、プロテ スタントを含む14宗派が存続を許されたが、その他は違法とされた。

注3）王政時代は宗教芸術省（Ministrul Cultelor şi Artelor,1944-1945）、芸 術省（Ministerul Artelor，1945-1947）。社会主義政権期の文化担当省庁 の履歴は以下のようになる。芸術省（Ministerul Artelor, 1947-1948）、 芸術情報省（Ministerul Artelor şi Informațiilor，1948-1949）、芸術省 (Ministerul Artelor, 1949-1950）、芸術委員会（Comitetul pentru Artă, 1950-1953)、文化省 (Ministerul Culturii, 1953-1957)、教育文化省 (Ministrul Învățământului şi Culturii，1957-1962）、文化芸術国家委員会 (Comitetului de Stat pentru Cultură și Artă, 1962-1971)）、社会主義文 化教育常務委員会 (Consiliul Culturii și Educației Socialiste, 19711989)

注4) Florin Abraham, Romania since the Second World War - A Political, Social and Economic History, Bloomsbury Academic, London, Oxford, 2016, p. 47

注5) Ion Dogu Balan with the co-operation of the Directorates of the Council of Socialist Culture and Education: Cultural Policy in Romania, The UNESCO Press, Paris, 1975, pp.22-24

注6）1974年の第11回ルーマニア共産党大会において採択した「共産主義者の 仕事と生活ならびに社会倫理と公正性に関する綱領」では理想的人間像に 関する31点が整理され、社会主義に生きる「新しい人間」が提示された。

注 7) Mihai C. Bocarnea, Bramwell Osula: Edifying the New Man Romanian Communist Leadership's Mythopoeia, International Journal of Leadership Studies, Vol.3. Iss.2, 2008, p. 207

注8) Ştefan Lupu Balş（1902-1994）。ブカレスト高等学校建築コース (1921-1927年) 卒業後、ローマのルーマニア・アカデミーへ留学 (1928-1929)。ローマ・ラ・サピエンツア大学建築学部にて、イタリアの 修復プロジェクトを研究。1930年から1950年の廃止までブカレストの歴史 的記念物委員会に技師として勤務。1953年「ルーマニア国土体系化・都市 計画研究所」 (ISPROR - Institutului de Sistematizare şi Proiectare a Oraşelor din România) 内に歴史的記念物局を設立。1960年からは建設 ・ 建築・国土体系化国家委員会 (Comitetului de Stat pentru Construcții, Arhitectura și Sistematizare $=$ CSCAS）の主任建築家として1978年の歴 史的記念物局廃止まで勤務。革命後、歴史的記念物委員会の委員となり、 歴史遺産保護体制の立て直しに貢献。1993年アカデミー名誉会員。

注9）ルーマニア正教会は国家教会として位置付けられていたことで、所管す る宗教課（Departamentul Cultelor）が1959年まで暫定的に教会建築の維 持修理を行っていた。

注10) Christian Vasile, Proiecte de Reorganizare a Direcției Monumentelor Istorice în Anni 1960, Studii şi Cercet. Ist. Art., Artă Plastică, serie nouă, tom 3 (47), Bucureşti, 2013, pp.151-155

注11) Pompiliu Macovei (1911-200)。イオン・ミンク建築大学卒業、建築家 として活躍し、戦後、ブカレスト市の主任建築家として1950年代の社会主 義リアリズムの都市計画を主導。ルーマニア建築家協会会長を経て文化芸 術国家委員会委員長（文化大臣）、外務国家委員会副委員長（外務副大臣） 等の要職を歴任。

注12）1960年代後半の映画ブームについて映画史の分野では、当時のルーマ ニア映画が多用した古代ダキア人の衣装から「ペプルム黄金時代」と評さ れる。Aurelia Vasile 'Industrie cinemtographique roumaine au service de la nation. Les enjeux de la production des films sur l'antiquité durant la période communiste', in Bogdan C. Iacob, History of Communist in Europe (Vol.III) Communism, Nationalism, and State Building in Post-War Europe, ZETA Books, Bucharest, 2012, pp.147-167

注13) Constantin Burduce (生没年不詳) 大戦中にルーマニア民主司祭連盟 (Uniunea Preoților Democrați Români) に参加。戦後の1945年にペトル・ グローザ政権の宗教大臣に任じられるが翌年には解任、1948年には亡命、 
南米に渡る。

注14）総主教ユスティニアン・マリーナ（Justinian Marina,1901-1977, 在 位1948-1977）は、オルテニアのルムニク・ヴルチャ小教区の司祭で妻帯 していたが（妻は1933年に死去）、収容所から脱走したゲオルギュ=デジ をかくまった縁で、彼と親交を結ぶようになる。1945年に大司教、1947年 に府主教に叙階。翌1948年に総主教の座に就くことになったのはゲオルギ ユ=デジの支援があったといわれる。

注 15) Lavinia Stan, Lucian Turcescu: Religion and Politics in PostCommunist Romania, Oxford University Press, Oxford / New York, 2007, pp.65-89

注16) $1959-60$ 年の1年間に 92 の正教会の教会・修道院が閉鎖、多くの司祭、 修道士、修道女が投獄された。それでも100あまりの修道院は残る。Florin Abraham, op.cit. p.50

注17) Lavinia Stan, Lucian Turcescu, op.cit. pp.18-25

注18) Nestor Vornicescu: Desăvîrşirea unității naostre naționale, fundament al bisericii străbune, Editura Mitropoloei Olteniei, Craiova, 1988, quotated in Olivier Gillet: Religion et nationalisme - L'Idéologie de l'Eglise roumaine sous le régime communiste, Edition de l'Université de Bruxelles, 1997, p.83

注19) Ion Scurtu: Politică şi viață cotidană in România - în secolui al XX-lea şi începutul celui de al XXI-lea, Editura Mica Valahie, Bucureşti, 2012, pp.325-326

注20) Principalele Lucrări de Restaurare a Monumentelor Istorice din Republica Socialistă România (1959-1969), Bultinul Monumentelor Istorice, Anul XXXIX, Nr.1, 1970, pp.71-76

注 21）ルーマニアの文化予算は1970年で $921,700,000 レ イ 、 1974$ 年で 1,039,600,000レイである。歷史遺産の保存修復事業費はそのおおよそ $15 \%$ に対応する。Ion Dodu Balan with the co-operation of the Directorates of the Council of Socialist Culture and Education, op.cit. p.63

注22）1970年の公定レートで1 US\$=1,667 Romanian leu

注23) Mănăstirea Hurezi (Vâlcea) は、コンスタンチン・ブルンコヴェヌに より1690-1709年に建設された。ブルンコヴェネスク様式芸術の傑作であ ること、壁画とイコンの芸術性が、ブルガリアやモルドヴァなどの近隣諸 国やバルカン地域の宗教芸術・建築に大きな影響を与えたことが評価され、 1993年にユネスコ世界遺産に登録された。

Mănăstirea Sucevița（Sceava）はゲオルグ・モヴィラ府主教により 1582-1584年建設、1595年に北・南面扉口を増築、1601年またはその数年 内に壁画が完成した。2010年に世界遺産「モルドヴァの教会群」に追加登 録された。

注24）原語では“accentuarea intervențiilor actuale prin tratarea lor în spirit contemporan”, "Principalele Lucrări de Restaurare a Monumentelor Istorice din Republica Socialistă România (1959-1969)”, op.cit. pp. $71-76$

注25) Ioana Grigorescu (1915-2006)、1941年にイオン・ミンク建築大学を卒 業、設計事務所に勤務した後、母校の助手となる。1950年代に入り、修復 建築家として歴史的記念物局のプロジェクトを担当するようになり、モル ドヴァ地方の一群の建築に加えて、セク、シハストリア修道院などを手掛 ける。ヴィクトール・ダン・キシレヴィッチ：建築家イオナ・グリゴレス ク、三宅理一・羽生修二監修: モルドヴァの世界遺産とその修復ールーマ ニアの中世修道院美術と建築, 西村書店, 2009, pp.253-270

注26) Sanda Ignat: Arhitectul Ştefan Balş Despere Restaurarea Monumentelor, (Interview avec l'architecte Şt. Balş, personalité proéminente de l'architecture de restauration roumaine) Buletinul Comisiei Monumentelor Istorice, Anul II, Nr. 4, Bucresti, 1991, pp.49-54

注27）ヴオロネッツ旧修道院の修復は 1962-1970年にかけて行われ、イオア ナ・グリゴレスクが担当した。当初は聖堂・付属施設の修復ならびに宿舎 の建設がなされ、壁画修復は1980年代に入って開始された。

注28）国土の「体系化」（sistematizare）が国の政策概念として公式に提示 されたのは1967年12月の共産党大会とされるが、実際にはゲオルギュ=デ ジ政権下で国土計画の指針として既にこの用語が掲げられている。

注 29）その間、 $27.1 \%(1956), 32.0 \%(1966)$ の数值を示す。Per Ronnås: Urbanization in Romania - A Geography of Social and Economic Change since Independence, The Economic Research Institute, Stockholm School of Economics, Stockholm, 1984, pp.198-206

注30）チャウシェスク時代のルーマニアの地方自治は、ソ連をモデルとして 導入された行政管区 (raion) 制が1968年になって王政時代の県制度に戻さ れ、県（județ）、市／村の二層からなっていた。基礎自治体は人口1万人 を目途に村 (comună) と市（oraş）に分類され、都市化政策の過程で多く の村が半ば人為的に市に格上げとなった。村の数は3000ほどで、都市化の 促進によって市の数は148市（1948）、171市（1956）、184市＋238郊外 村（1966）、233市（1968）、237市（1989）と増加する。加えて、都市 化目標の達成のため、1956年以降、都市の指標が再編成され、村でありな がら市と同格とみなされる「都市型集落」（localități de tip urban）が多 く出現した。これらは法的には村であるが、人口は都市人口とみなされる。 1956年の国勢調査では183の「都市型集落」が出現し、その人口は全都市 人口の $13.3 \%$ にんだ。1989年には543の都市型集落が存在した。Benedek József: Urban Policy and Urbanization in the Transition Romania, Romanian Review of Regional Studies, Vol.II, Nr.1, 2006, pp.51-64

注31) Lege nr. 58/1974 ("Buletinul Oficial" 1 noiembrie 1974), privind "Sistematizarea teritoriului și localităților urbane și rurale"

注32) Ilarion Țiu: Ceaușescu și problema sistematizarii rurale, Sfera Politicii, Vol. 22 Issue 2, mar/apr 2014, pp.9-15

注33) Vasile Cucu: Sistematizarea teritoriului şi localităților din România Editura Ştiințifică şi Enciclopedică, Bucureşti, 1977, p.207

注34）1974年の国土体系化法（Legea nr. 58/1974“, în Buletinul Oficial nr. 135, 1 noiembrie 1974）は、西側諸国であれば農村計画法と都市計画法を 兼ねたものであるが、その主たる目的が農村部の都市化にあり、規制と誘 導によって都市の適度の発展計画を促すというよりは、産業施設の再配置 にともない農村を無理やりコンパクト化して都市的な中心市街地をつくり 出すことが主眼で、実態としてはゲットー的な不良住宅地を数多く生むこ とになった。

注35) Grigore Ionescu (1904-1992)。ローマのルーマニア・アカデミー留学 生（1931-1933）、1930年代後半からルーマニアの歴史的建造物に関する 研究を始め、建築遺産保護の分野で活躍。イオン・ミンク建築大学教授、 歴史的記念物局長（1963-1966）を歴任。1991年にアカデミー会員。

注36) Grigore Ionescu: Necesitatea sistematizării şi restaurării entrelor istorice, Buletinul Monumentelor Istorice, Anul XXXIX, nr. 1, anul 1970, pp. $37-40$

注37）1975年7月1日から4日にかけて発生した大洪水は、ルーマニア南東部の シレット川、アルジェス川、プラホヴァ川、ブザウ川などの氾濫により $60,000 \mathrm{~km}^{2}$ の冠水地域をもたらした。

注38）ヴランチャ地震は、1977年3月 4 日の夜半に発生したマグニチュード 7.5 の地震。32,897棟の建造物に被害（住戸 742,259 戸、社会施設 8,228 棟）、 1,527 名の死者（うち1,424名はブカレスト）、負傷者 11,221 人に及んだ。 ICCPDC(Institutul Central de Cercetare, Proiectare şi Directivare în Construcții) Report, 1978

注39) Sanda Ignat, op.cit. pp.49-54 


\title{
ORTHODOX CHURCH AND HERITAGE POLICY IN EARLY CEAUŞESCU PERIOD
}

A study on heritage management and role of World Heritage in post-socialist Romania - 1

\author{
Maiko TATEZAKI*1, Toshikazu HANAZATO *2 and Riichi MIYAKE ${ }^{* 3}$ \\ ${ }^{* 1}$ Senior Researcher, Japan Cultural Heritage Consultancy, M.Eng. \\ (Grad. Student, Graduate School of Engineering, Mie University) \\ ${ }^{* 2}$ Prof., Graduate School of Engineering, Mie University, Dr.Eng. \\ ${ }^{*}$ Visiting Prof., Tokyo University of Science, Dr.Eng.
}

Socialist regimes in Eastern Europe carried out harsh repression on religious institutions, but in Romania, the regime was flexible compared with Soviet Union, where Orthodox monasteries were closed by force and torn down. Romanian way of "carrot-and-stick" tactics to the Orthodox Church watered down the resistance of certain clergies and believers while the religious monuments were acknowledged as the tool for the national identity. This paper focuses on the formation of the heritage policy and its implementation by the socialist government vis-à-vis the monastic tradition in Romania.

Three parties should be analysed in terms of the intervention for conservation: State, Orthodox Church and the experts of historical monuments. The official competent body for heritage conservation was formed under the state committees for culture and national planning, but as long as this section was not adequately evaluated by the regime tops, this became nearly an asylum of the experts who continued their identity from the kingdom period and kept liberal attitude by working with local church communities.

The Direcție a Monumentelor Istorice (DMI), started in 1959, played a key role for implementing the restoration works for the Church. This direction kept taking the initiative until the middle of 1970's. According to the budgetary table of their operations during the 1960's, three among 39 counties and Bucharest received the benefit of high ratio of the budget: Suceava in Moldavia (15.7\% of national budget for conservation), Braşov in Transylvania (12.7\%) and Constanța in Wallachia (10.4\%). Since the first is the cradle of Romanian Orthodox Church, the conservation works for such monasteries as Voronet and Dragomirna were considered crucial. In the second, it was fortification rather than Protestant Church. The third signifies the sites of Roman antiquities. In the monasteries like Voroneț, closed by the secularization policy in the late 19th century, DMI paradoxically accelerated the pace of conservation due to the absence of the church intervention.

In the cases of Suceavița, Doragomirna and Vorneț, the restoration works should be underlined by the contemporary spirit. This was played by an architect Ioana Grigorescu. These three projects occupied more than $70 \%$ of the total budget in Suceava County (11\% of the national budget). The analysis of her preserved documents reveals that, besides the restoration of the authentic church buildings, nuns' cells, dining halls and even exhibition halls were specially designed with dynamic forms inspired by the Romanian tradition.

In Romania special terminology for urban planning "systematization” had been employed since 1920's but during the socialist period, Marxist connotation with scientific and top-down approach was added so as to form a nation-wide planning conception, which obliged urbanization by migration of rural population. Conservation of historical monuments was so seriously affected by this planning policy that the church communities on comună (village) level suffered enormously. The rehabilitation of historical cities such as Craiova and Constanța were recognized important in the early 1970's responding to the trend of the West, but Vrancea Earthquake of 1977 suspended this movement and squeezed DMI to a much smaller section.

In this sense, the balance among the triangle State - Church - Professional was barely stabilized, despite its sensitiveness, in the early period of Ceauşescu Regime. Input to the conservation policy by timely contact with UNESCO played the role of counter-balance against the pressure of systematization by the leaders of the socialist hierarchy. 